\title{
FUNGSI BADAN NARKOTIKA NASIONAL (BNN) DAN POLISI DALAM TINDAK PIDANA NARKOTIKA
}

\author{
I Made Karnadi, I Nyoman Gede, Ida Ayu Putu Widiati \\ Fakultas Hukum Universitas Warmadewa, Denpasar-Bali, Indonesia \\ imdkarnadi98@gmail.com,nyomansugiartha14@gmail.com, idaayuwidiatifhwjurnal@gmail.com
}

\begin{abstract}
Abstrak
Pencegahan terjadinya penyalahgunaan narkotika yang dilakukan dikalangan remaja anak-anak hingga dewasa serta pemberantasan peredaran narkotika ditangani oleh suatu lembaga yaitu Badan Narkotika Nasional dan Polisi. Badan Narkotika Nasional berwenang melakukan penyidikan dan penyelidikan Polisi juga memiliki kewenangan yang sama dengan Badan Narkotika Nasional. Penelitian ini bertujuan untuk menjelaskan fungsi Badan Narkotika Nasional dan Polisi dalam tindak pidana narkotika yang kedua menganalisis sinergitas Badan Narkotika Nasional dengan Polisi dalam Penyelidikan dan Penyidikan terhadap tindak pidana narkotika. Metode penelitian yang digunakan adalah penelitian hukum normatif dengan pendekatan perundang-undangan konseptual. Data yang digunakan data hukum primer dan sekunder yang dianalisis secara kualitatif. Hasil penelitian menunjukan bahwa fungsi Badan Narkotika Nasional adalah pencegahan dan pemberantasan penyalahgunaan narkotika Sedangkan fungsi Polisi adalah menangkap melakukan penyelidikan dan penyidikan serta memberantas peredaran gelap narkotika yang kedua Sinergitas Badan Narkotika Nasional dengan Polisi dilakukan dengan cara koordinasi dalam hal menangani tindak pidana narkotika dimulai dari penyelidikan assessment terhadap pelaku sampai proses pengawalan persidangan dan eksekusi.
\end{abstract}

Kata Kunci: Narkotika; Tindak Pidana; BNN

\begin{abstract}
Prevention of narcotics abuse committed among adolescent children to adults and the eradication of narcotics trafficking is handled by an institution, namely the National Narcotics Agency and the Police. The National Narcotics Agency has the authority to carry out investigations and police investigations also have the same authority as the National Narcotics Agency. This study aims to explain the function of the National Narcotics Agency and the Police in narcotics crime. Secondly, to analyze the synergy between the National Narcotics Agency and the Police in Investigation and Investigation of narcotics crime. The research method used is normative legal research with a conceptual statutory approach. The data used were primary and secondary legal data which were analyzed qualitatively. The results of the study show that the function of the National Narcotics Agency is the prevention and eradication of narcotics abuse, while the function of the Police is to arrest investigations and investigations and eradicate illicit narcotics against the perpetrators until the process of escorting the trial and execution.
\end{abstract}

Keywords: Narcotics; Criminal act; BNN

\section{PENDAHULUAN}

Masyarakat Indonesia saaat ini sedang berjuang melawan maraknya gejolak penggunaan obat terlarang yang sering disebut narkoba. Narkotika memang sangat bagus untuk bidang kesehatan dan juga pengobatan itu dikarenakan narkotika berasal dari tanaman sintesis maupun semi sintesis yang bisa dijadikan sebagai obat hilangnya rasa nyeri menyebabkan penurunan kesadaran bahkan menimbulkan ketergantungan (Mustamin, 2015). Menurut Hanifah \& Unayah, (2011) Selain berasal dari tanaman narkotika bisa dibuat dengan zat atau bahan pemula atau bahan kimia yang bisa disebut dengan prekursor narkotika. Namun penggunaan narkotika banyak sekali disalahgunakan sehingga terjadinya candu berlebihan Penegakan hukum terhadap peredaran gelap narkotika sangat tegas penegasan tersebut dikarenakan peredaran gelap narkotika merupakan suatu perbuatan yang melawan hukum sehingga bisa ditindak pidana.

Badan Narkotika Nasional merupakan ujung tombak dalam memerangi tindak pidana narkotika sehingga membentuk tim assesment terpadu yang terdiri dari berbagai profesi mulai dari kesehatan psikologi dan juga kepolisian guna melaksanakan dari perintah Undang-Undang Nomor 35 Tahun 2009 tentang Narkotika yang menginstruksikan bahwa terhadap seseorang yang menggunakan atau 
kecanduan terhadap narkotika direhabilitasi tanpa dihukum oleh tim rehab dari badan narkotika nasional. Tim dari penyidik Badan Narkotika Nasional yang masuk dalam sub Tim Brantas tetap berkoordinasi dengan kepolisian setempat untuk bersama-sama melakukan tindakan-tindakan terhadap pengedar ataupun kurir yang nantinya di tindak lanjuti dalam proses hukum dengan menggunakan dasar hukum Undang-Undang Nomor 8 Tahun 1981 tentang Hukum Acara Pidana. Untuk penyempurnaan dibidang hukum yang khusus mengatur mengenai narkotika dalam menunjukkan keseriusannya mencegah serta memberantas narkotika, pemerintah memformat Badan Narkotika Nasional (BNN) yang merupakan Lembaga pemerintah non kementerian yang berdomisili dibawah dan bertanggung jawab pada presiden (Bagus et al., 2020). Terjadinya norma yang bertentangan terkait dengan wewenang Badan Narkotika Nasional dan Polisi yang mana ditinjau dari pasal 4 Peraturan Presiden Nomor 23 Tahun 2010 bahwa tugas pemberantasan peredaran gelap narkotika dan prekursor narkotika Badan Narkotika Nasional berwenang melakukan penyidikan dan penyelidikan namun dalam hal ini polisi juga memiliki kewenangan yang sama.

Ada beberapa penelitian terdahulu yang relevan dengan penelitian ini Nadhira, (2010) melakukan penelitian tentang Optimalisasi Fungsi Penyidikan oleh Badan Narkotika Nasional. Penelitian lain mengunkapkan bahwa dalam mengatasi penyalah gunaan narkoba diperlukan pola hubungan fungsional baik antara BNN dengan Lapas dalam penanganan narkotika di Lapas kedepannya sehingga saling kordinatif, dalam bentuk bentuk penanganan preventif dan represif yang didasari dengan nota kesepakatan antara BNN dengan Lapas (Imran, 2013). Faktor yang mempengaruhi kerjasama BNN dan Kepolisian adalah faktor pendukung adanya informasi dan komitmen yang bagus sedangkan faktor penghambat yaitu kurangnya sumber daya manusianya yang tidak lain dari aparat kepolisian (Junaedi et al., 2019). Penelitian ini bertujuan untuk untuk menjelaskan fungsi Badan Narkotika Nasional dan Polisi dalam tindak pidana narkotika yang kedua menganalisis sinergitas Badan Narkotika Nasional dengan Polisi dalam Penyelidikan dan Penyidikan terhadap tindak pidana narkotika

\section{METODE PENELITIAN}

Penelitian ini didesain menggunakan penelitian hukum normatif karena dilihat dari sudut kajian tipe penelitian hukum normatif ini lebih cocok mengangkat materi kepustakaan yaitu melalui sumber-sumber seperti buku jurnal dan undang-undang. Pendekatan-pendekatan yang digunakan adalah pendekatan Perundang-undangan dan juga pendekatan konseptual Pendekatan Perundang- undangan adalah pendekatan yang dilakukan menggunakan Undang-Undang dan peraturan hukum lain. Data yang digunakan bersumber dari bahan hukum primer yaitu Undang-Undang Dasar Negara Republik Indonesia 1945 peraturan perundang-undangan berupa Kitab Undang-Undang Hukum Pidana (KUHP) Kitab Undang-Undang Hukum Acara Pidana (KUHAP) Undang-Undang Nomor 35 Tahun 2009 tentang Narkotika Undang-Undang Nomor 2 Tahun 2002 tentang Kepolisian Negara yang kedua bahan hukum sekunder yaitu teori hukum yang digunakan untuk memecahkan persoalan yang diteliti yang berasal dari bebrapa literature.

\section{HASIL DAN PEMBAHASAN}

\section{Fungsi Badan Narkotika Nasional dalam mencegah terjadinya Tindak Pidana Narkotika}

Fungsi Badan Narkotika Nasional ditinjau dari pasal 3 Peraturan Presiden Nomor 23 Tahun 2010 tentang Badan Narkotika Nasional Bahwa BNN memiliki kewenangan dalam hal membuat suatu kebijakan baik kebijakan strategis terkait dengan tindak pidana narkotika dan prekursor. Dimana tindak pidana narkotika merupakan: Perbuatan pidana yang dilakukan oleh subjek pidana yang menggunakan zat atau obat yang dilarang oleh undang-undang yang dapat menyebabkan penurunan atau perubahan kesadaran hilangnya rasa mengurangi sampai menghilangkan rasa nyeri dan dapat menimbulkan ketergantungan baik pelaku maupun orang lain.

Menurut Rodliyah, (2017) Tindak pidana narkotika itu sendiri disebutkan bahwa orang yang menggunakan zat berbahaya atau obat terlarang tersebut bisa mengakibatkan dampak yang negatif bagi orang yang telah melakukan perbuatan pidana maupun orang lainnya sehingga pengguna zat atau obat terlarang itu mengakibatkan rusaknya saraf otak yang mengakibatkan penurunan daya ingat dan juga kesadaran dan juga menyebabkan ketergantungan terhadap zat atau obat berbahaya tersebut.

Tim assesment terpadu memiliki peranan penting dalam hal menangani kasus narkotika Selain polisi Tim Assesment Terpadu ini berasal dari Badan Narkotika Nasional yang berwenang dalam hal menangani penyalahgunaan narkotika yang nantinya para tim dokter dan juga tim medis yang akan 
melakukan pengecekan terhadap korban atau pengguna narkotika. Proses pemeriksaan dilakukan secara hati-hati oleh Tim Assesment Terpadu karena tersangka pidana itu sendiri juga mempunyai hak-hak sebagai tersangka yang patut juga dilindungi oleh hukum yang berlaku.

Hak-hak tersangka pidana sangat penting untuk dilindungi oleh hukum karena tersangka biasanya merupakan pihak yang diambil sebagian kemerdekaan pribadinya misalnya dia ditangkap ditahan disita barangnya dan sebagainya Padahal hak-hak seperti itu merupakan hak yang sangat penting bagi seseorang Karena itu hukum perlu benar-benar menjamin dan mengawasi agar pengambilan hak tersangka tersebut tidak dilakukan secara sewenang-wenang atau secara berlebih-lebihan (Fuady \& Fuady, 2016). Perlindungan hak-hak seperti itu sangat penting bagi seseorang Untuk sebab itu hukum perlu menjamin adanya perlindungan hak terhadap seseorang. Berdasarka undang-Undang yang mengatur tentang perlindungan Hak Asasi Manusia telah dicantumkan dalam Undang-Undang Nomor 39 Tahun 1999 tentang Hak Asasi Manusia.

Fungsi utama dari kepolisian adalah menjaga keamanan dan ketertiban di wilayah Indonesia serta memberikan perlindungan pengayoman dan juga pelayanan terhadap masyarakat, polisi juga berperan aktif dalam penegakan hukum di Indonesia Pengemban fungsi kepolisian tersebut juga dibantu oleh kepolisian khusus penyidik pegawai negeri sipil. Dalam proses pemeriksaan terhadap seseorang yang tertangkap tangan sebagaimana diatur dalam KUHAP sebagai berikut:

1 Menurut Pasal 102 ayat (2) dan (3) KUHAP bahwa dalam hal tertangkap tangan tanpa perintah penyidik penyelidik wajib segera melakukan tindakan yang diperlukan dalam rangka penyelidikan sebagaimana tersebut pada Pasal 5 ayat (1) huruf b, selanjutnya Terhadap tindakan yang dilakukan tersebut pada ayat (2) penyelidik wajib membuat berita acara dan melaporkannya kepada penyidik sedaerah hukum

2 Menurut Pasal 111 KUHAP bahwa: (1) Dalam hal tertangkap tangan setiap orang berhak sedangkan setiap orang yang mempunyai wewenang dalam tugas ketertiban ketenteraman dan keamanan umum wajib menangkap tersangka guna diserahkan beserta atau tanpa barang bukti kepada penyelidik atau penyidik (2) Setelah menerima penyerahan tersangka sebagaimana dimaksud dalam ayat (1)

3 Penyelidik atau penyidik wajib segera melakukan pemeriksaan dan tindakan lain dalam rangka penyidikan

Proses penangkapan yang dilakukan polisi terhadap seseorang yang tertangkap tangan tanpa perintah penyidik berawal dari penyelidik guna melakukan penangkapan terlebih dahulu Selanjutnya penyelidik membuat berita acara dan melapor ke penyidik guna proses pemeriksaan dalam rangka penyidikan (Sofyan \& Asis, 2014). Pidana penjara memang memberikan dampak yang buruk bagi psikologis seseorang itu diakibatkan praktik di dalam pemasyarakatan kurang berkembang dan berjalan dengan baik. Pemberian sanksi berupa pidana penjara kepada terpidana pengedar narkotika sudah sesuai dengan keputusan pengadilan Hal ini diberikan untuk memberikan efek jera terhadapterpidana pengedar narkotika Namun disatu sisi pidana penjara memang lebih buruk ketimbang rehabilitasi korban pengguna narkotika pidana penjara tetap menimbulkan efek yang buruk meskipun praktik pemasyarakatan sampai saat ini belum jauh beranjak dari sistem penjara yang dipraktikkan selama pemerintahan kolonial maupun pasca kemerdekaan (Zaidan, 2015).

\section{Sinergitas Badan Narkotika Nasional dengan Polisi dalam Penyelidikan dan Penyidikan terhadap tindak pidana narkotika}

Koordinasi antara Badan Narkotika Nasional dengan Polisi dalam menangani tindak pidana narkotika sangatlah penting Badan Narkotika Nasional merupakan lembaga yang paling berperan dalam rehabilitasi korban tindak penyalahgunaan narkotika sedangkan polisi menangani tindak pidana narkotika biasanya dalam hal upaya pemberantasan pengedaran narkotika.

Rehabilitasi Pasal 97:

1) Seorang berhak memperoleh rehabilitasi apabila oleh pengadilan diputus bebas atau diputus lepas dari segala tuntutan hukum yang putusannya telah mempunyai kekuatan hukum tetap

2) Rehabilitasi tersebut diberikan dan dicantumkan sekaligus dalam putusan pengadilan sebagaimana dimaksud dalam ayat (1)

3) Permintaan rehabilitasi oleh tersangka atas penangkapan atau penahanan tanpa alasan yang berdasarkan undang-undang atau kekeliruan mengenai orang atau hukum yang ditetapkan sebagaimana di maksud dalam Pasal 95 ayat (1) yang perkaranya tidak diajukan ke 
pengadilan negeri di putus oleh hakim praperadilan yang di maksud dalam pasal 77 (Lamintang \& Lamintang, 2010).

Pengedar narkotika akan berurusan dengan pihak kepolisian dimana polisi melakukan penangkapan penyelidikan dan penyidikan terhadap pengedar dan bandar narkotika sebagai upaya pemberantasan peredaran gelap tindak pidana narkotika. Kepolisian adalah sebagai aparatur Negara dan birokrasi pemerintahan. Fungsi polisi secara universal adalah membasmi kejahatan (fighting crime) memelihara ketertiban (maintaining law and order) dan melindungi warga dari bahaya (protecting people) (Wajdi \& Lubis, 2019). Setiap bidang profesi hukum baik dari Badan Narkotika Nasional dan juga Polisi memiliki fungsi dan perannya masing-masing dalam melaksanakan tugasnya sebagai profesional hukum yang harus memiliki sikap manusiawi adil patut dan jujur dalam hal melaksanakan kewajibannya sebagai penegak hukum terutama dalam hal tindak pidana narkotika.

Kewenangan Penyelidikan dilakukan oleh pihak dari kepolisian yang bertugas sebagai penyelidik dan penyidik. Dalam kamus besar bahasa Indonesia kata kewenangan berasal dari kata dasar wenang yang berarti kuasa untuk melakukan sesuatu sehingga kewenangan memiliki arti kuasa untuk melakukan sesuatu. Kewenangan dalam disiplin ilmu hukum dikenal dengan istilah competentie (Effendi, 2014). Wewenang dari penyelidik menurut Kitab Undang-Undang Hukum Acara Pidana yaitu menerima pengaduan dari seseorang terkait adanya suatu tindak pidana narkotika Penyelidik akan mencari keterangan yang berkaitan dengan laporan atau pengaduan yang diberitahukan oleh seseorang tersebut guna memastikan apakah laporan itu benar adanya atau tidak Jika pengaduan seseorang itu benar maka penyelidik segera melakukan pencarian barang bukti terkait dengan pengaduan tersebut dan juga memeriksa seseorang yang telah dicurigai oleh penyelidik

\section{SIMPULAN DAN SARAN}

\section{Simpulan}

Berdsarkan analisis data dapat disimpulkan bahwa Badan Narkotika Nasional mempunyai fungsi dalam hal penyusunan dan perumusan kebijakan nasional dalam bidang pencegahan dan pemberantasan penyalahgunaan narkotika. Tim Asesmen yang dimiliki Badan Narkotika Nasional mempunyai peranan dalam hal penanganan pengecekan terhadap korban atau pengguna narkotika yang dilakukan oleh para ahli dibidangnya Fungsi polisi dalam tindak pidana narkotika adalah menangkap melakukan penyelidikan dan juga penyidikan serta memberantas peredaran gelap narkotika, yang kedua bahwa Badan Narkotika Nasional (BNN) bersinergi dengan polisi dalam mengungkapkan terjadinya dugaan Tindak Pidana Narkotika yang diawali dari penyelidikan, penangkapan, penggeledahan dan tindakan lain sebagai upaya membuat terangnya dugaan tindak pidana narkotika Selanjutnya dilakukan upaya penyidikan guna untuk mencari titik terang tindak pidana serta mengumpulkan barang bukti guna menemukan tersangkanya sedangkan Badan Narkotika Nasional akan melakukan suatu pengecekan terlebih dahulu sebelum dilakukannya tahap rehabilitasi jika seseorang yang tertangkap itu merupakan korban penyalahgunaan narkotika

\section{Saran}

Adapun yang disarankan oleh peneliti sesuai dengan hasil penelitian ini adalah kepada petugas supaya melakukan upaya penindakan sesuai dengan undang-undang yang mengatur setiap instansi baik dari Badan Narkotika Nasional dalam rehabilitasi korban penyalahgunaan dan juga Polisi dalam hal Penangkapan tersangka peredaran gelap narkotika sangat kuat dalam hal memberantas tindak pidana narkotika, yang kedua Koordinasi BNN dengan kepolisian terus dikembangkan lebih baik lagi sebab upaya kerjasama ini sangat diprioritaskan dalam mencegah dan memberantas peredaran gelap narkotika dan penyalahgunaan narkotika

\section{DAFTAR PUSTAKA}

Bagus, I., Setiaawan, T., Ayu, I., Widiati, P., \& Sudibya, G. (2020). Peranan Badan Narkotika Nasional (BNN) Dalam Upaya Pencegahan Terhadap Tindak Pidana Narkotika. 2(3), 361-365.

Effendi, T. (2014). Dasar-dasar Hukum Acara Pidana. Setara Press.

Fuady, M., \& Fuady, S. L. L. (2016). Hak Asasi Tersangka Pidana. Prenada Media Group.

Hanifah, A., \& Unayah, N. (2011). Mencegah dan Menanggulangi Penyalahgunaan Napza Melalui Peran Serta Masyarakat. Informasi, 16(1), 33-46.

Imran, M. A. (2013). Hubungan Fungsional Badan Narkotika Nasional dengan Lembaga Pemasyarakatan dalam Penanganan Narkotika di Lembaga Pemasyarakatan. Kajian Hukum Dan Keadilan, 1(2), 327-345. 
Junaedi, Harakan, A., \& Idris, E. I. P. (2019). Kerjasama BNN dan Kepolisian dlam Penanggulangan Penyalahgunaan Narkoba di Kecamatan Rappocini Kota Makassar. Jurnal Moderat, 5(1), 81-95.

Lamintang, P. A., \& Lamintang, T. (2010). Pembahasan KUHAP Menurut Ilmu Pengetahuan Hukum Pidana dan Yurisprudensi. Sinar Grafika.

Mustamin. (2015). Studi tentang Penyebab Penggunaan Narkoba Dikalangan Remaja di Kelurahan Penana'e Kecamatan Raba Kota Bima. Jime, 1(2), 237-249.

Nadhira, N. (2010). Optimalisasi Fungsi Penyidikan oleh Badan Narkotika Nasional. Jurnal Kriminologi Indonesia, 6(3), 246-259.

Rodliyah. (2017). Hukum Pidana Khusus Cetakan. PT Rajagrafindo Persada.

Sofyan, A., \& Asis, H. A. (2014). Hukum Acara Pidana Suatu Pengantar. Kencana Media Grup.

Wajdi, F., \& Lubis, S. K. (2019). Etika Profesi Hukum. Sinar Grafika.

Zaidan, M. A. (2015). Menuju Pembaruan Hukum Pidana. Sinar Grafika. 